\title{
The Participatory Museum and Distributed Curatorial Expertise
}

\section{Thomas Söderqvist}

The series of commentaries in this journal about university collections and museums raises a number of issues, which are otherwise rarely brought up in discussions about the historiography of science, technology, and medicine. Anke te Heesen points to the often forgotten fact that university collections are an integral part of many fields of university research and teaching (te Heesen 2008); this active role of the collections in the primary functions of the university is therefore an important parameter to take into account when developing acquisition and exhibition agendas for university museums. Christian Sichau warns against the rapidly deteriorating political, intellectual, and economic status of traditional curatorial work in collections (Sichau 2009); this is a serious long-term threat to museums because the current trend towards blockbuster exhibitions and event culture-even in science, technology, and medical museums-undermines the role of the museum as a space for the preservation of the heritage and the acquisition of new artefacts. Thomas Schnalke in this issue, finally, largely ignores the question of collections, artefact curating, and new acquisitions in favour of an inspiring discussion about the potentially great role of museum exhibitions in science communication, both internally in the university and externally for a larger general public.

All three authors have long-term experience from the science, technology, and medical museum world. Together, their contributions provide an excellent platform for future discussions about the role of collections in museums in general and in university 
museums in particular. In this commentary I restrict myself to an important issue brought up by Sichau-and which neither te Heesen nor Schnalke pays much attention to-viz, how science, technology, and medicine museums should handle the problem of new acquisitions. How should they manage the steadily growing output of scientific, technical, and medical artefacts, documents, and images from offices and research laboratories? Should they at all try to catch up with the perpetual tsunami of potential collection items? Should they try to bring in almost everything, or should they restrict themselves to samples (and if so, what are the rules of the sampling game)? Should they have a global focus or should they concentrate on objects produced and/or used in the local university (and if so what does 'locally produced' and 'locally used' actually mean in a world with increasingly globalised knowledge and artefact production)? Or should museums let the event logic of their outreach staff determine what to collect, so that they bring in an electron microscope only if an exhibition on microscopy is in the pipeline-and refuse to accept it if the outreach people plan for an obesity show instead?

Sichau is in favor of a severely restrictive attitude to new acquisitions. He develops his argument for a next-to-zero collecting policy in opposition to a short appeal made in Physik Journal in March 2008 under the title "Bitte nicht wegwerfen!", in which historian of science Klaus Hentschel gave a chilling example of the accidental destruction of some of the important sources for the history of early German solid state physics. Hentschel called on physicists to be more aware of their heritage, and asked them to contact archives and museums before throwing out older material of any kind.

Sichau takes Hentschel's appeal as his point of departure for articulating a deliberately pessimistic position. Because there is very limited space available in museums, the daily routine for curators is to reject, rather than accept, new objects. Furthermore, contemporary objects are not spectacular enough for exhibitions; they neither give us clues to the historical past nor relate to what goes on at the frontiers of science, technology, and medicine today. Finally, the need for public outreach more often than not trumps the need to preserve the heritage, and today's exhibitions tend to rely rather on dramatic multimedia than objects anyway. So even if there may be good scholarly reasons for collecting objects, "werde ich als Kurator 'Nein' sagen müssen" (89), concludes Sichau. 
If I had agreed with Sichau's arguments, I would never have devoted so much energy to trying to represent the material culture of contemporary science, technology, and medicine. As director of Medical Museion at the University of Copenhagen I have chosen to focus our efforts-our research, our acquisitioning activities, and our public outreach-precisely on late twentieth century and contemporary medical science and medical technology, and I have come to rather different conclusions than Sichau.

All museum people are familiar with the problems that Sichau is confronting, and I can easily understand why he expresses such defeatist views. I too believe that the acquisitioning and keeping of contemporary science instruments and artefacts is a very demanding task for museums, especially university museums. The current cultural and political climate places university museums uncomfortably between, on the one hand, a museum logic that favors the creation of spectacular public shows and events and, on the other hand, the prevailing logic of university departments, which is to publish as many often-cited scholarly papers in highranked journals as possible.

Today's university museum is placed somewhere between these two entrenched logics. This borderline position is problematic, because curating scientific instruments, technological devices, and medical artefacts does not necessarily lead either to popular blockbuster shows or to a steady flow of articles in highimpact journals. Acquiring and curating material artefact, image, and document collections all too easily becomes a neither-nor; an unspectacular and invisible activity resulting in insignificant publications in low-ranked journals.

In contrast to Sichau, I am not pessimistic, because I believe these problems occasion a number of interesting challenges: intellectual, logistic, and political (see Söderqvist/Bencard 2008, Söderqvist/Bencard/Mordhorst 2009). I see opportunities rather than obstacles. I therefore believe that we should, as a rule, say "Yes, please" when we get a chance to collect visual, material, and textual objects from contemporary laboratories and storage rooms. I suggest that we should even, in Hentschel's spirit, actively promote the acquisition of such objects. In other words, not only should we not be restrictive, we should indeed open up the sluice gates. An optimistic "Yes, please" policy is nicer and wiser than a pessimistic "Nein" policy.

My argument is based on my experiences from Medical Museion's integrated research and curatorial program 
"Biomedicine on Display" (http://www.corporeality.net/museion). The program was launched in 2005 with the explicit intention to lay the research foundation for the acquisition and public outreach of the visual and material culture of late twentieth century and contemporary biomedicine-a time period which so far has been very sparsely represented in museums of science, technology, and medicine.

During the past four years we have run a number of research projects on a variety of aspects of late twentieth century and contemporary biomedicine. Parallel to these research projects, we have set up a series of exhibitions with more or less explicit connection to contemporary science, starting with 'Oldetopia' (on aging research and the cultural understanding of aging) in 20072008, followed by 'Design4Science' (on molecular and cultural object design) and 'Eye Catchers and Swagger Images' (about scientific posters as art objects) in the spring of 2009. In June 2009, we opened 'Split + Splice: Fragments from the Age of Biomedicine,' curated by artist Martha Fleming together with four postdoctoral fellows in the program, showing the complexities of contemporary biomedicine through the material culture, objects, and instruments used by researchers and clinical practitioners; and, finally, in September 2009 we launched 'Primary Substances: Treasures from the History of Protein Research', which displays a number of iconic artefacts from twentieth century protein research in the light of the ambiguous notion of 'treasure'.

These research projects and exhibitions have occasioned the collection of a large number of recent artefacts from laboratories and hospitals in the Copenhagen region. Some artefacts were chosen to satisfy the needs of the exhibitions, others were unsolicited donations from university laboratories, hospital clinics, and pharmaceutical and medical device companies, and others again were the result of active collecting. We have an acute lack of space and certainly do not have enough professional curatorial staff to take care of everything properly. Registration is constantly lagging behind. Nevertheless we rarely say "No". In some concrete cases we have, with some trepidation, done so, but not as a general policy. Why?

Basically, I suggest, because a "Yes, please" policy opens up a whole array of fruitful interactions between museums and practitioners of science, technology, and medicine. Indeed, it promises to change the way science, technology, and medical museums place themselves in relation to the rest of the university. Instead of 
seeing the university museum as a closed repository for exquisite objects guarded by professional curators, a "Yes, please" policy is an open invitation to every single researcher, technician, and student at the university to become adjunct curators of their own heritage.

Sichau is right in the sense that museums will never be able to employ enough professional curators to describe, register, and evaluate every single artefact and image in the university's laboratories and storage rooms. But with the help of our colleagues in science, technology, and medicine, we can create a distributed curatorial expertise. In the domain of business management this is referred to as by 'crowdsourcing', a term coined by Jeff Howe in a Wired magazine article in 2006. Wikipedia defines it as a "distributed problem-solving and production model":

\begin{abstract}
Problems are broadcast to an unknown group of solvers in the form of an open call for solutions. Users-also known as the crowd-typically form into online communities, and the crowd submits solutions. The crowd also sorts through the solutions, finding the best ones. These best solutions are then owned by the entity that broadcast the problem in the first place-the crowdsourcer-and the winning individuals in the crowd are sometimes rewarded. [...] Crowdsourcing may produce solutions from amateurs or volunteers working in their spare time, or from experts or small businesses which were unknown to the initiating organization.
\end{abstract}

Crowdsourcing is only one of many social technologies for participatory knowledge production that have emerged in recent years; technologies that are conceptually related to the general notion of 'web 2.0'. In contrast to 'web 1.0', which stands for a one-way flow of information from producers and providers of web information to readers/users, 'web 2.0' stands for a knowledge and information architecture that facilitates the transformation of passive web users into active producers. The quantitative and qualitative success of Wikipedia is the best example of the participatory web; similarly, projects like Foldit (http://fold.it) and Galaxy Zoo (http://www.galaxyzoo.org), which enroll hundreds of thousands of web users into the active production of scientific knowledge in protein chemistry and astronomy, respectively, have been enormous successes.

In analogy to the notion of 'web 2.0', museologists like Nina Simon (http://museumtwo.blogspot.com) have coined the notion of 'museum 2.0'. Simon's idea is not primarily to employ social web media as tools in museum outreach, but rather to rethink the physical museum in terms of the conceptual apparatus of 'web 2.0'; i.e., the participatory museum as an analogy to the participatory web. The ambitious task is to reconceptualise all activities of the 
museum-research, acquisitions, curating, exhibition creation, other kinds of outreach-in terms of user participation, user creativity, and distributed knowledge. With respect to the acquisitioning of scientific, technological, and medical artefacts, this means that everyone who deals with potential museum artefacts in his/her daily work in universities and other research institutions is a potential curator. The goal for the museum is to transform these potential curators into active participants in the acquisition and curating of collections ('crowd acquisitioning').

Social technologies like distributing, curating, and crowd acquisitioning do not by themselves solve the space problem. However, one of the implications of the participatory museum is that its collections do not necessarily have to be physically located in a central museum building. If curating and curators can be distributed, so can collections. The idea of a distributed museum collection is not a central museum with peripheral repositories to which only the professional curators have keys and access, but should rather be understood as a network of local collections of different sizes and richness, each managed by its local adjunct curator, who makes decisions about acquisitions, curating, and storage. Most departments in most universities have their own small collections, sometimes just a small cupboard with a few objects that are kept for commemorative and nostalgic reasons. The governing role of the central museum vis-à-vis the distributed museum collection is then primarily to offer advice in the form of guidelines for 'best museum practice' in acquisitions and curating.

The implementation of a network of distributed museum collections not only promises to solve some of the problems with lack of storage space. It may also become an instrument for raising the historical awareness and responsibility of practitioners-curators. Instead of employing more professional staff to amass, curate, and register artefacts in the central museum repository, scarce resources may be better used by training practitioner-curators to become gatekeepers that build relations between the museum and the rest of the university. Instead of doing all the curatorial work themselves, professional museum curators should rather work out guidelines for how the network of distributed curators should curate and preserve; the professionals should also distribute protocols for registration in a wiki-based central database; and, most importantly, they should spend much time and energy raising discussions among the practitioners of why the scientific, technological, and medical heritage is worth keeping and its role in the 
creation of cultural identity. In short, their job is to build a distributed curatorial experience.

Much of this is hardly new. Many local and regional museums have worked along these lines long before the concept 'museum 2.0' was coined. Many science, technology, and medical museums once started as participatory collecting projects initiated by enthusiastic practitioners who created small local collections, some of which still remain in the custody of departments and scientific societies. Medical Museion is a case in point. Today the museum has one of Europe's largest, richest, and most varied collections of medical artefacts of all kinds-but it once started as a private initiative by Copenhagen doctors on the occasion of the 50th anniversary of the Danish Medical Association in 1907. Initially conceived as a collection of contemporary medical devices for a temporary show to commemorate the progress of medicine since the founding of the Association in 1857, the collection was made permanent and the museum continued to grow, largely thanks to the enthusiasm of the contributors, and it continued to do so for at least two or three generations.

Today, such participatory acquisition practices have largely been abolished. The progressive professionalisation in science, technical, and medical museums throughout the twentieth century has made such practices look amateurish and antiquated. However, I believe it is time to rethink the advantage of bringing practitioners of science, technology, and medicine into more active roles in the work of acquisitioning and curating. Citizenscience projects such as fold.it and Galaxy Zoo are excellent examples of how this can be done in principle, although the specific features of museum knowledge production (material artefacts) is an extra challenge to overcome (citizen-museums cannot be run in the virtual space only). At Medical Museion we have only recently begun to experiment with different ways of mobilising practitioners for the acquisition and preservation of the recent and contemporary scientific, technological, and medical heritage. We have made, and continue to make, lots of mistakes, but our experiences tell us that it is a route worth taking-and that it is a route that contradicts Sichau's pessimistic "Nein" attitude.

Another route for overcoming the space and resource problem is to strengthen the co-operation between museums. Sichau's pessimistic view is quite understandable as long as museums think of themselves as regional or national actors with a comprehensive mandate; not even giants like Deutsches Museum, Science 
Museum in London, or the Smithsonian in Washington, D.C., have the staff, time, and money to embark on a systematic (or even a systematically selective) acquisition program that covers all of contemporary science, technology, and medicine.

Except for occasional collaborative projects at the interpersonal level, museums of science, technology, and medicine do not have a tradition of working closely together. Museums act as if they are international competitors rather than collaborators and as if each is in principle responsible for the preservation of the entire scientific, technological, and medical heritage. And because this is in practice impossible (unless we develop very radical distributed collecting procedures as outlined above), the failure to live up to the principle leads to the kind of defeatism that Sichau expresses in his article.

Currently, a group of major science, technology, and medical museums are attempting to create a pan-European co-operative project with respect to the digitalisation and public online access to images of artefacts in the participating institutions. But there have so far not been any attempts to establish a co-operative acquisition and curating program in which museums agree on how to divide the scientific, technological, and medical heritage between them-biomedical laboratory equipment in one, solid state physics in another, imaging technologies in a third, etc.

True, there are hundreds of local and regional collections of science, technology, and medicine all over Europe which have, by historical accident, developed rather narrow collections. Such collections have often been fairly comprehensive in their own right: for example, the splendid collection of surgical instrument and medical instrument catalogues at the Thackray Museum in Leeds, or the collection of eighteenth and early nineteenth century pathological specimens in the Hunterian Museum in London. But as far as I know there are no examples of museums that have deliberately divided the acquisition and curating tasks among them-especially not when it comes to late twentieth century and contemporary science, technology, and medicine.

Admittedly, this is not an easy task. No museum, especially not a national museum, will easily give up its ambitions to comprehensiveness. No museum will by itself abstain from some areas of acquisitioning and let one of its national or regional competitors take over that domain of objects. Even if they do not have the resources today, and even if they practice a restrictive "Nein" policy in daily work, the ambition is still to cover everything. To 
give chunks of the potential artefact spectrum away to other museums, be they national or regional, is therefore not something that comes easily. Would Science Museum just abstain from collecting artefacts from nanotechnology and nanomedicine and let Deutsches Museum take over this burgeoning field? Would Medical Museion stop collecting artefacts from contemporary protein research even if we realised that another European museum maybe had better resources and a more skilled staff to do this?

This is just one of the problems involved in working out a common European policy for acquisitioning the contemporary scientific, technological, and medical heritage. Other problems include the administrative work involved and how to develop a continuously updated list of the enormous number of artefacts (for example, in the field of medical device technology, a new patent is granted every $38 \mathrm{~min}$, many of which are produced in co-operation with medical or engineering departments at universities).

In conclusion: Christian Sichau's provocative commentary has had a positive effect. His pessimistic "Nein" position forces us to think of constructive ways of overcoming what at first sight looks like an impossibility. The notions of the participatory museum and distributed curatorial expertise are real alternatives to a defeatist and restrictive acquisitioning policy. University museums should instead cultivate the audacity of curatorial hope for the preservation of the scientific, technological, and medical heritage. So in principle, yes please, let's collect everything.

\section{Acknowledgments}

I thank Gustav Holmberg (University of Lund) for comments on a late version of the manuscript.

\section{References}

te Heesen, Anke, 2008. In medias res. Zur Bedeutung von Universitätssammlungen. NTM. Zeitschrift für Geschichte der Wissenschaften, Technik und Medizin, 16, 485-490.

Hentschel, Klaus, 2008. Bitte nicht wegwerfen! Allzu oft werden Quellen der Physikgeschichte achtlos entsorgt, statt sie zu sichern. Physik Journal, 3, 3.

Howe, Jeff, 2006. The Rise of Crowdsourcing. Wired, 14, URL: http://www. wired.com/wired/archive/14.06/crowds.html [accessed 1 October 2009]. 
Sichau, Christian, 2009. Einstein, interaktiv und zum Anfassen. Oder: die drohende Auflösung des Museums? NTM. Zeitschrift für Geschichte der Wissenschaften, Technik und Medizin, 17, 85-92.

Söderqvist, Thomas/Bencard, Adam, 2008. Making Sense or Sensing the Made? Research into Presence Production in Museums of Science, Technology and Medicine. In: Görel Cavalli-Björkman and Svante Lindqvist (Eds), Research and Museums. Stockholm: Nationalmuseum, 161-173.

Söderqvist, Thomas/Bencard, Adam/Mordhorst, Camilla, 2009. Between Meaning Culture and Presence Effects. Contemporary Biomedical Objects as a Challenge to Museums. Studies in History and Philosophy of Science, 40, 431-438.

Thomas Söderqvist

Medical Museion

University of Copenhagen

Fredericiagade 18

1310 Kopenhagen K

Denmark

Email: ths@sund.ku.dk 